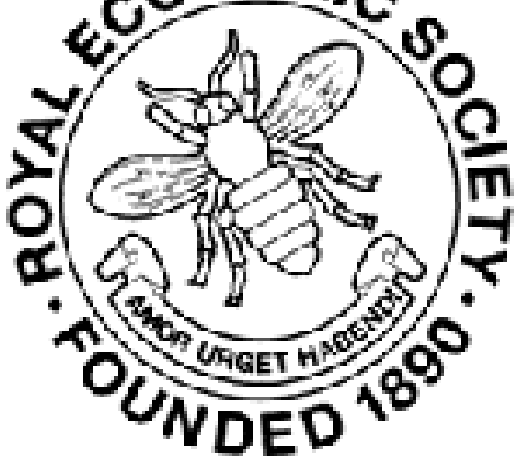

\title{
Professor J. S. Nicholson on 'Consumers' Rent'
}

Author(s): F. Y. Edgeworth

Source: The Economic Journal, Vol. 4, No. 13 (Mar., 1894), pp. 151-158

Published by: Wiley on behalf of the Royal Economic Society

Stable URL: http://www.jstor.org/stable/2955886

Accessed: 25-06-2016 21:46 UTC

Your use of the JSTOR archive indicates your acceptance of the Terms \& Conditions of Use, available at

http://about.jstor.org/terms

JSTOR is a not-for-profit service that helps scholars, researchers, and students discover, use, and build upon a wide range of content in a trusted digital archive. We use information technology and tools to increase productivity and facilitate new forms of scholarship. For more information about JSTOR, please contact support@jstor.org.

Royal Economic Society, Wiley are collaborating with JSTOR to digitize, preserve and extend access to The Economic Journal 
Two Deaths from Phthisis in the Family.

\begin{tabular}{|c|c|c|c|c|c|c|}
\hline \multicolumn{4}{|c|}{ MaLes. } & \multirow{2}{*}{\multicolumn{3}{|c|}{$\begin{array}{c}\text { FEMales. } \\
\text { Number of Deaths. }\end{array}$}} \\
\hline \multirow{3}{*}{$\begin{array}{l}\text { Age. } \\
\text { Years. }\end{array}$} & \multicolumn{3}{|c|}{ Number of Deaths } & & & \\
\hline & \multirow[b]{2}{*}{ Actual. } & \multicolumn{2}{|c|}{ Expected. } & \multirow[b]{2}{*}{ Actual. } & \multicolumn{2}{|c|}{ Expected. } \\
\hline & & $\begin{array}{c}\text { According } \\
\text { to General } \\
\text { Table. }\end{array}$ & $\begin{array}{c}\text { According } \\
\text { to } \\
\text { Phthisical } \\
\text { Table. }\end{array}$ & & $\begin{array}{c}\text { According } \\
\text { to General } \\
\text { Table. }\end{array}$ & $\begin{array}{c}\text { According } \\
\text { to } \\
\text { Phthisical } \\
\text { Table. }\end{array}$ \\
\hline $\begin{array}{r}1-15 \\
15-35 \\
35-65\end{array}$ & $\begin{array}{r}9 \\
54 \\
46\end{array}$ & $\begin{array}{r}2 \cdot 4 \\
23 \cdot 3 \\
36 \cdot 1\end{array}$ & $\begin{array}{r}4 \cdot 5 \\
32 \cdot 4 \\
41 \cdot 2\end{array}$ & $\begin{array}{r}3 \\
42 \\
40\end{array}$ & $\begin{array}{r}1 \cdot 7 \\
17 \cdot 9 \\
34 \cdot 1\end{array}$ & $\begin{array}{r}2 \cdot 1 \\
30 \cdot 1 \\
31 \cdot 6\end{array}$ \\
\hline Total.......... & 109 & 62 & 78 & 85 & 54 & 64 \\
\hline & & ree Deaths $f$ & om Phthisis & the Fam & & \\
\hline $\begin{array}{r}1-15 \\
15-85 \\
35-65\end{array}$ & $\begin{array}{r}4 \\
15 \\
17\end{array}$ & $\begin{array}{r}0 \cdot 5 \\
7 \cdot 3 \\
11 \cdot 9\end{array}$ & $\begin{array}{r}1 \cdot 0 \\
10 \cdot 1 \\
13 \cdot 5\end{array}$ & $\begin{array}{r}1 \\
14 \\
14\end{array}$ & $\begin{array}{r}0 \cdot 4 \\
4 \cdot 9 \\
10 \cdot 3\end{array}$ & $\begin{array}{l}0 \cdot 4 \\
8 \cdot 3 \\
9 \cdot 7\end{array}$ \\
\hline Total.......... & 36 & 20 & 25 & 29 & 16 & 18 \\
\hline
\end{tabular}

The mortality is thus much greater than in families where only one death from phthisis has taken place, this being consequently an aggravating circumstance taking into consideration the health of applicants, nevertheless even the additional premiums covering the extra risk for such persons would not be unattainable for the applicants.

These observations are, as explained above, incomplete and in. sufficient, but I hope that this paper may at least induce others to take up the same question, and may afford some help to those who do so.

\section{Harald WestergaARd}

\section{Professor J. S. Nicholson on 'Consumers' Rent.'}

THE measurement of the gain or loss resulting to consumers from the change of the price of an article-technically termed Consumers' Rent--is of some practical, and great theoretical, interest.

Employing the principle, though not the term, Dupuit long ago drew important conclusions concerning the utility of canals and other means of communication, and the rates which should be charged for their use.1 In an improved form the doctrine of Consumers' Rent is employed by Professor Marshall to confute the maxim that no work which will not 'produce an income sufficient to defray the interest on its cost' can 'be worth the labour spent on it.' ${ }^{2}$ Even more original con-

1 See the references given in the article on Dupuit in Palgrave's Dictionary of Political Economy.

${ }^{2}$ Principles of Economics, Book V., ch. xiii., § 8. p. 524, 2nd Ed. 
clusions are deduced by him concerning the effects of taxes and bounties. ${ }^{1}$ For instance, the receipts from a tax (or expenditure on a bounty) may in certain cases exceed the loss (or be exceeded by the gain) of the consumer. Of course such conclusions are weakened in practice by the imperfection of Governmental action and other concrete circumstances to which Professor Marshall alludes. ${ }^{2}$

The theoretical interest of the principle under consideration is even greater. To take only one branch-international values-the theory of Consumers' Rent supplies what is wanting in Mill's treatment of the subject when, as pointed out by Jevons, ${ }^{3}$ he treats value as the measure of the benefit which a nation derives from its trade. How serious the omission made by Mill may prove is shown by the example of Cournot, who, in his estimate of the advantages of Free Trade, deliberately neglects the advantage derived by consumers from the extension of their purchases in consequence of a fall of price, 'parce que cet avantage n'est pas numériquement appréciable.' ${ }^{4}$ I should be inclined to attribute the paradoxical character of Cournot's conclusions principally to the neglect of Consumers' Rent, rather than with Professor Bastable to the 'desire to discover a scientific basis for Protectionism' 5 disturbing a usually serene judgment.

But the theoretic interest of Consumers' Rent is not confined to Economics in its narrower definition, the province of supply and demand. The principle concerns the publicist as affording the most perfect example of utilitarian calculus. Some of the writers who have best treated of the relation of utility to value have lent the weight of their authority against utilitarianism. Thus, Dr. Bonar writes, ${ }^{6}$ 'All that mathematical economics needs to assume is that a material quantity of goods will be in a certain proportion to a greater or less strength of motive.' Professor Marshall has not committed himself to a theory on the ultimate principle of action. ${ }^{7}$ But his practice appears to me to meet the objection to utilitarianism on which speculative philosophers, such as T. H. Green and even Dr. Bonar, have relied largely; that the summation of pleasures and comparison of the sums is inconceivable or unworkable. Consider the following passage :

'If we take averages sufficiently broad to cause the personal peculiarities of individuals to counterbalance one another, the money which people of equal incomes will give to obtain a pleasure or avoid a pain is an extremely accurate measure of the pleasure or the

1 Principles of Economics, Book V., ch. xii.

2 Loc. cit., § 6.

3 Theory of Political Economy, ch. iv., section on The Gain by Exchange. Cairnes in his treatment of the subject (Leading Principles, Part III., ch. v., § 2) may seem to be feeling after the principle of Consumers' Rent. 'What is the true criterion of the gain on foreign trade? I reply, the degree in which it cheapens commodities and renders them more abundant.'

4 Principes Mathématiques, p. 159. Cf. ibid., p. 154.

5 International Trade, Appendix C, p. 173.

6 Philosophy and Political Economy, p. 224.

7 In his speech at the meeting of the British Economic Association in 1893 (EconomIC Journal, vol. iii. p. 388 et seq.) he uses language similar to Dr. Bonar's. 
pain. If there are a thousand persons living in Sheffield, and another thousand in Leeds, each with about $£ 100$ a year, and a tax of $£ 1$ is levied on all of them, we may be sure that the loss of pleasure which the tax will cause in Sheffield is almost exactly equal to that which it will cause in Leeds ; and similarly anything that increased all the incomes by $£ 1$ would give command over almost exactly the same amount of additional pleasure in the two towns.' 1

'Differences may generally be neglected when we consider the average of large numbers of people. If those numbers include rich and poor in equal proportions, aggregate price becomes a fair measure of utility.' ${ }^{2}$

What Bentham called 'lots of happiness,' thus treated, appears to me at least, ponderable and almost palpable. ${ }^{3}$

That an advance in this direction should be unanimously received was not to be expected. Of the objections which have been raised against the doctrine of Consumers' Rent, none are more deserving of attention than those which Professor J. S. Nicholson has inserted in his splendid Principles of Political Economy. ${ }^{4}$ I regret that I have not an opportunity of expressing my estimate of Professor Nicholson's authority by considering his volume as a whole; and that my reference to the work is confined to the one passage which does not command my admiration and assent.

The points in Professor Nicholson's criticism which seem to deserve special notice may be arranged under three main heads. ${ }^{5}$

I. Utility cannot be measured by money. This objection presents three subdivisions.

(a) Money is at best a measure of utility for one individual. ${ }^{6}$

1 Principles, Book III., § 2, p. 185.

2 Ibid., marginal note.

3 The use of the principle of averages which distinguishes Professor Marshall's treatment of problems relating to utility is less explicitly contained in what Bentham says about ' chance of happiness.' (Propositions of Pathology, Part I., ch. 6 ; Works, vol. I., p. 305, ed. 1843). It is indeed implicit in common-sense. Professor Marshall, as I interpret the passage above quoted, only claims to put into exact language a part at least-Bentham might claim the whole-of what ordinary people mean when they speak of one tax as causing a greater amount of distress than another which brings in an equal revenue.

${ }^{4}$ Book I., ch. iii., \$\$ 3-7, and Note on Professor Marshall's Treatment of Consumers' Rent.

5 There are indeed many side hits which I am prevented from parrying by a regard for brevity and unity, and by the well-known difficulty of refuting a witticism.

For example, in the note on p. 56, Professor Nicholson says: 'Those who have most logically tried to carry out the measurement of utility by price have been forced to the conclusion that value depends only on utility. $C f$. Dr. Smart's Theory of Value, p. 8.' But what if the implied compliment to the Austrian school is not deserved!

Again, at the end of the note on p. 65, Professor Nicholson says : "No expansion of the formula, "the more we have the less we want," can be a sufficient substitute for the enumeration of the many actual conditions which govern the consumption of wealth and the prices of commodities and services.' The remark derives its pungency from the insinuation that Jevons and Professor Marshall have treated the general laws of utility as a substitute for more concrete information. Their whole work shows that they have not.

${ }^{6}$ Loc. cit., p. 54, par. 2 , sub fin. ; p. 55, par. 4 ; p. 57, par. 1 ; p. 59 , pars. 2 and $3 ; 65$. 
'We can never get beyond one individual.' We should otherwise have to 'assume that all the buyers have the same incomes and the same tastes, and in fact are in all respects similar.' 1

Undoubtedly there is a great gulf between one's own and other people's feelings. But it must be leaped over by common sense, and bridged by sympathy. ${ }^{2}$

Once it is admitted that other people's pleasures exist and may be reckoned like one's own, they come under the category of quantity, and are amenable, like other quantities, to the law of averages; so as to admit of conclusions like Professor Marshall's above cited. 'The loss of pleasure which the tax will cause in Sheffield is almost exactly equal to that which it will cause in Leeds.'

Referring to this passage Professor Nicholson says:

' But the conclusion is purely formal ; the important point is that a tax of $£ 1$ per head would impose burdens on the members of the community ranging from zero to the pains of starvation, eviction, beggary and the like. The principle of equality of sacrifice cannot be simplified in the manner proposed.' 3

But, as I understand, Professor Marshall asserts equality of sacrifice, not between different classes in either Leeds or Sheffield, but between 'a thousand persons living in Sheffield, and another thousand in Leeds.' Professor Marshall is scrupulously careful to speak of money as measuring pleasure only with reference, either to an individual, or a group of persons among whom rich and poor, sensitive and phlegmatic natures, are distributed in normal proportions. The cautious use of the principle of averages which Professor Marshall has again and again insists on ${ }^{4}$ appears to me to fully meet the difficulty which Professor Nicholson finds in the diversity of individual dispositions.

$(\beta)$ But even for the individual money does not measure utility.

We may ... . look upon a man as earning money by labour and in reality exchanging his labour against commodities by means of money. In this case we should suppose that he would go on working until the disutility or discomfort of earning another penny was just greater than the utility or comfort of spending this extra penny. Here, however, we are only comparing the utility (say) of an extra pipe with the disutility of an extra quarter of an hour's labour.

'The penny does not measure either the utility or the disutility. It throws no light whatever on the question how much pleasure he feels in smoking or how much pain in working.' 5

'A clinical thermometer will measure accurately the heat of the body, but it says nothing of the corresponding feeling. Heat is one thing as a mode of motion-another as a sensation.' 6

1 P. 57 , par. 1 ; p. 59.

2 The practical postulate is well stated by Dr. Venn in his Empirical Logic, p. 569.

3 P. 64.

${ }^{4}$ See, in addition to the passage already cited and its context, Principles, pp. 542-3 where a want of caution in this respect on the part of Jevons is noticed.

5 Professor Nicholson's Principles, p. 56.

6 Ibid. P. 60, note. 
I admit that a penny does not measure utility in the same sense as a yard measure, length ; and I accept the analogy of the thermometer as fair, and even favourable. ${ }^{1}$ But once more I fall back upon common sense, and what Hume would call a sceptical solution of sceptical doubts. 'Nature will always maintain her rights,' as he says. 'These principles may flourish and triumph in the schools where it is indeed difficult to refute them; but, as soon as they leave the shade and by the presence of real objects which actuate our passions and sentiments are put in opposition to the more powerful principles of our nature, they vanish like smoke.' Indeed it is not necessary to leave the schools in order to be convinced that by taking the thermometer as a measure of sensation, the comfort both of an individual and a class may be promoted. In a school of which I know orders are given, in the interest both of the teacher and the taught, that the temperature should be kept at $60^{\circ} \mathrm{Fahr}$. In the reading-room of the British Museum the temperature is maintained at $65^{\circ}, \mathrm{I}$ know not in whose interest. I am disposed to think that the comfort of the studious public would be increased if the temperature were reduced from $65^{\circ}$ to $60^{\circ}$; judging from the emphatic complaints about the excessive heat which I have heard many readers express. When during the fiery season of last August the fanning apparatus designed to cool the readingroom failed to act, there were those who thought that the public money expended in making the heat uncomfortable in winter might be advantageously diverted to securing a desirable cool in summer. But an attempt on the part of the Governing Body to promote the comfort of the students by such an adjustment must appear to Professor Nicholson futile. 'Heat,' he would remind the languid reader, 'is one thing as a mode of motion, another as a sensation.' The marginal disutility of over-heating cannot be measured by the degrees of a thermometer, unless all the readers have the same clothes and the same studies, ' and in fact are in all respects similar.' '

$(\gamma)$ There remains the objection that 'if utility . . . . were measurable in terms of money, then we ought to be able to measure in terms of money not merely the utilities that possess exchange value but others equally. . . . But we cannot express even the marginal utility of sunshine in terms of price.' 3 I reply (1) of the cases thus excepted, some are not exceptions. I have heard of lodgings with access to sunshine fetching a higher rent than others less advantageously situated. (2) The failure of the exchange test may in other cases be regarded as in a sense accidental, like the failure of the thermometer through the freezing or volatilising of the liquid at certain temperatures. If, as Professor Simon Newcomb imagines, the inhabitants of another planet made an offer to us terrestrials for our moon, we should soon find that this natural object had an exchange value. (3) But probably this

${ }^{1}$ On the measurement of sensation consider Dr. Voigt's proposal to use only ordinalnot cardinal-numbers, referred to on p. 202 of the present number of the Journal.

2 P. 57, first par. and p. 60, first line.

${ }^{3}$ P. 56, par. 4. 
instance, on account of the magnitude of the transaction, and certainly many others of the exceptional subdivision, would fall under the second general head to which I proceed.

II. Professor Nicholson has sought to represent the principle of Consumers' Rent as unworkable by applying it to a case expressly excluded by Professor Marshall-viz., the measurement of the P entire utility obtained from necessaries. He has done so not from inadvertence like Professor Patten, ${ }^{1}$ who has lately been corrected by Professor Marshall himself, but apparently on the tacit assumption that if the principle is true on a small scale, it must be also on a great one. This is a logic which it would be very dangerous to employ in Natural Philosophy.

Here is a piston, $\mathrm{PQ}$, driven downwards in a smooth tube of uniform bore, ${ }^{2}$ closed at the lower extremity, against air compressed within the tube. As long as we confine ourselves to relatively small movements, it is correct enough to say that the work done by the piston is proportioned to the length through which it moves. Thus A B is to A C (approximately) as the work done by the piston in moving from $\mathrm{A}$ to $\mathrm{B}$ is to the work done by it in moving from $\mathrm{A}$ to $\mathrm{c}$. But the work done in moving from $\mathrm{A}$ to $\mathrm{Y}$ is not to be measured by the length $\mathrm{AY}$. For the change in the pressure attending the change in the volume of the air cannot in this, as in the former case, be neglected. When Professor Nicholson argues with respect to the measurement of utility by money: "it is clear that in all cases we must consider the marginal utility of money, ${ }^{3}$ it is just as if he argued with respect to the measurement of work done by our piston: " it is clear that in all cases we must consider the variation of the pressure due to a change of volume.' The very genius of applied calculus consists in not considering such variations when they are of an order of magnitude which may be neglected. When he argues, that ' if the utility of the first portion is "indefinitely great" when measured by price, the price also must be "indefinitely great," " 4 it is just as if he argued that, since the work done by the piston in moving from $\mathrm{y}$ or $\mathrm{z}$ is very great or infinite, therefore the length AY, or A $z$, which measures that work, must be indefinitely great in comparison with $\mathrm{AB}$. But who said that in this case the length moved was a measure of the work done?

The loss to Professor Nicholson's cause from the rejection of this

1 In the Annals of the American Academy, replied to by Professor Marshall in the same periodical.

2 There would be some advantage in conceiving the bore as not uniform; and measuring the work done by the space through which the piston (the plug $\mathrm{Q}$ expanding or contracting so as to fit to the tube) is moved.

${ }^{3}$ P. 64, par. 1.

4 P. 63, par. 3 . 
argument is much greater than the advantage which might have been obtained by it. For his having used it is apt to create an unfavourable impression, impairing the authority of the writer with respect to the particular subject in hand. It is thus that bimetallists might feel if a distinguished monometallist should misconceive one of their stock arguments ; asserting, for instance, that ' gold has not varied more than 3 per cent.,' in a sense of 'appreciation' quite different from that which the bimetallist argument requires. Even those who had the highest respect for the abilities of the eminent objector and his authority in fiscal matters would be sensible that in this particular case his utterances deserved less attention than usual. A similar impression may be created in some readers by the passages to which I have just adverted, and by others like the following:-

'When we try to introduce a number of other people, our conclusion is still more barren; for now all we are entitled to say is that somebody at some point will find that the price is such that he is willing to purchase just one more portion at that price. But of the rest of the multitude some would have been satisfied to pay a higher price for their last portion, and some are not willing to pay that price. So that the price measures the final utility to this individual (and others exactly similar), and as before it only measures it in terms of the utility he and they attach to the money spent.' ${ }^{1}$

Considering that the subject is, in Professor Marshall's words, 'the exact measurement of the Consumer's Rent in a market,' the distinction drawn between the purchasers is not an appropriate conception. In economic equilibrium the price measures the final utility for each individual. ${ }^{2}$

Professor Nicholson's difficulty under this head is summed up in the following passage -

'On p. 184 (note) [of Professor Marshall's Principles] it is stated "that it is seldom possible to get the data necessary for drawing the demand curve complete." But, unless the demand curve is complete, we cannot get the totcl utility, or the Consumer's Rent; above all, we cannot get the total utility to the community.' 3

I reply that, if 'it is seldom possible,' it is also seldom needful ' to get the data necessary for drawing the demand curve complete.' For as Professor Marshall goes on to explain in the note referred to, our chief concern is not with the aggregate of satisfactions to the community, but with their changes. It is of use to us to know whether the thermometer is at $60^{\circ}$, or at $65^{\circ}$, even though we do not know to how many negative degrees we should have to go before finding absolute zero.

III. The crown of Professor Nicholson's objections consists in the interrogation, ' Of what avail is it to say that the utility of an income

1 P. 59, par. 3.

2 P. 59.

3 P. 65, par. 2. A hasty reader of this passage might easily make a confusion, unduly favourable to the argument, between the total utility corresponding to the complete demand curve and a portion of that volume ; since the smaller aggregate might be called total, as being an integral of which marginal utility is the differential. 
of $£ 100$ a year is worth, say, $£ 1,000$ a year?' as he finds in the case of an example designed to 'show in the clearest way that the measurement of total utility by price is purely illusory.' 1

The gist of the difficulty, as I understand, is not the disproportion of the magnitudes 100 and 1,000 (which presents no difficulty), but the inexactness and indefiniteness of the result. First then it is to be observed that Professor Nicholson has exaggerated that inexactness by attempting to measure in money the complete utility derived from the entire income. This spurious specimen of Consumers' Rent being disallowed, the legitimate analogy of Professor Nicholson's example would be as follows:-To $x$ spent upon extras and luxuries corresponds a total utility equal to ten times $x$. 'Of what avail' is such a proposition? Well, certainly not for any purpose which requires the exactness of a commercial account, or even of a physical constant. Our result could in general claim only such accuracy as pertains to the rougher statistical calculations-such as the determination of the variation in the value of money, or in the amount of the national capital - calculations which Professor Nicholson has countenanced by making important contributions to them.

Thus understood, the proposition may avail to verify and illustrate many curious propositions in the theory of taxation - employing the term tax in the generalised sense of any change which may cause an increase in the supply price for each several amount of the commodity ; ${ }^{2}$ and to refute many unfounded assumptions on that subject. ${ }^{3}$

A more immediately practical application has been indicated already. ${ }^{4}$ Suppose that a tax must be imposed, or a railway rate fixed by Government, and that the amount of Consumers' Rent lost by the tax, or not obtained by the rate, were estimated to be according to one proposed plan $x$, and, according to another, $\frac{1}{2} x$; it would be advisable to adopt the latter rather than the former plan. This is a rough, but may be a useful, conclusion.

F. Y. EDGEWORTH

\section{Recent Writings on IndeX-Numbers.}

ONE of the problems which has exercised economists for some years, the determination of variations in the value of the monetary standard, bears some not wholly accidental resemblances to one of the problems which has exercised philosophers in all ages, the determination of the standard of moral action. With respect to both

1 P. 58.

2 Marshall, Principles of Economics, Book V., ch. xii., p. 4. See the remarks made above p. 152. See also in Auspitz and Lieben's Theorie der Preises the propositions relating to taxes and bounties on exports and imports. I venture also to refer to propositions which I have stated in the article on International Trade in another part of this number of the Journal, almost all deduced with the aid of the principle of Consumers' Rent.

3 For the negative use of the principle to dispel the vain appearance of knowledge, see Jevons's Theory, ch. iv., section on Gain by Exchange.

${ }^{4}$ Above, p. 151. 